\title{
Spatial and seasonal variations in the pelagic- benthic coupling of the southeastern Beaufort Sea revealed by sedimentary biomarkers
}

\author{
Nathalie Morata ${ }^{1, *}$, Paul E. Renaud ${ }^{1,2}$, Sonia Brugel ${ }^{3}$, Keith A. Hobson ${ }^{4}$, \\ Beverly J. Johnson ${ }^{5}$ \\ ${ }^{1}$ Department of Marine Sciences, University of Connecticut, 1080 Shennecossett Road, Groton, Connecticut 06340, USA \\ ${ }^{2}$ Akvaplan-niva, Polar Environmental Centre, 9296 Tromsø, Norway \\ ${ }^{3}$ Institut des sciences de la mer de Rimouski (ISMER), Université du Québec à Rimouski, 310 allée des Ursulines, Rimouski, \\ Québec G5L 3A1, Canada \\ ${ }^{4}$ Environment Canada, 11 Innovation Blvd., Saskatoon, Saskatchewan S7N OH3, Canada \\ ${ }^{5}$ Department of Geology, Bates College, 44 Campus Avenue, Lewiston, Maine 04240, USA
}

\begin{abstract}
Photosynthetic pigments and stable isotopes from suspended particulate organic matter (POM) and surface sediment of the southeast Beaufort Sea, including the Mackenzie shelf and the Amundsen Gulf, were studied during fall 2003 and summer 2004. This multiple-biomarker approach led to an increased understanding of spatial and seasonal variation in pelagic-benthic coupling, as these 2 biomarkers reflect inherent differences in the time scales over which they integrate. Sedimentary pigments highlighted the importance of local water-column production as a source of phytodetrital inputs to the sea floor. In the summer, the dominance of diatoms in the water column was reflected in the sediment by the abundance of fucoxanthin, a pigment broadly found in diatoms. In the fall, a more variable suite of sedimentary pigments reflected inputs from smaller cells such as haptophytes and prasinophytes. While stable isotope composition of the POM showed seasonal variations, i.e. a more marine signature in the summer and a more terrestrial signature in the fall, sedimentary stable isotopes revealed geographical differences. Sediment on the Mackenzie shelf suggested a terrestrial source of organic matter, while in the Amundsen Gulf, sources of organic matter had a more marine origin. Finally, benthic community compositions and activity (sediment carbon demand) seemed affected by both spatial and seasonal variations in organic matter inputs to the benthos. This study stresses the importance of both physical factors (water depth and riverine inputs) and biological production (primary productivity and secondary production) in the determination of organic matter inputs to the benthos.
\end{abstract}

KEY WORDS: Arctic · Sedimentary pigment • Pelagic-benthic coupling • Stable isotope . Carbon cycling $\cdot$ HPLC

\section{INTRODUCTION}

While the Arctic Ocean represents only $1 \%$ of the global ocean, it accounts for $25 \%$ of the world's continental shelves (Dittmar \& Kattner 2003). These shelves represent an important sink of carbon: the average organic carbon burial corresponds to 7 to $11 \%$ of the global budget (Stein \& Macdonald 2004). Organic fluxes to the sea floor depend on production and processes in the overlying water column. In particular, the quality as well as the quantity of biogenic matter fluxes can be determined by zooplankton grazing, which has a strong impact on pelagic-benthic coupling (Olli et al. 2002, Wexels Riser et al. 2008). When phytoplankton 
blooms and large zooplankton stocks coincide in space and time, grazing efficiency is high and sedimentation of intact phytoplankton cells is low, while when they are separated in space and time, grazing efficiency is lower and sedimentation is higher. The inputs to the sea floor are not always directly buried and can be used by the benthos. In some areas, much of the overlying production falls to the bottom, supplying rich and active communities of benthic organisms (Piepenburg 2005). Recent studies (e.g. Tremblay et al. 2002, Vidussi et al. 2004) have shown that primary production is much higher in the Arctic than previously believed, and in areas covered by ice, ice algae can be a major source of carbon for both pelagic and benthic food webs (Gosselin et al. 1997, Klages et al. 2004, Renaud et al. 2007a).

On a volume basis, the Arctic Ocean is the ocean with the highest terrestrial input in terms of freshwater and organic matter (Dittmar \& Kattner 2003), and thus terrestrial inputs can be an important source of organic matter to the benthos. The Mackenzie River is the fourth largest of all river systems discharging into the Arctic (Macdonald et al. 1998). Carbon input to the southeast Beaufort Sea, adjacent to the Mackenzie River, is derived primarily from 3 sources: marine biological production, the Mackenzie plume, and coastal and seabed erosion (O'Brien et al. 2006).

Climate models suggest that global warming effects in the Arctic are expected to be disproportionately higher than in temperate regions, and will increase riverine fluxes due to intensifying hydrological cycles (Peterson et al. 2002, Wu et al. 2005). Moreover, modifications of ice distribution and seasonality are expected to have an effect on primary production (Renaud et al. 2007b), probably favoring phytoplankton to the detriment of ice-algae production, affecting the entire food web and leading to changes in pelagicbenthic coupling (Carroll \& Carroll 2003). It is therefore very important to characterize organic matter pathways to the shelf of the Arctic basin. This study explores the nature of the organic matter supplied to the southeast Beaufort Sea, as a function of environmental factors, including productivity regime, riverine inputs, and ice conditions.

The study of sedimentary pigments is valuable for understanding spatial and seasonal variations of organic matter inputs to Arctic benthos (Morata \& Renaud 2008, and references therein). Chlorophyll (chl) $a$, a pigment present in all photosynthetic eukaryotes, has a half-life of approximately $3 \mathrm{wk}$ in polar sediments (Graf et al. 1995). Thus, sedimentary chl $a$ is a good indicator of the 'freshness' of the algal matter inputs to the sediment (Boon \& Duineveld 1996), while its degradation products (phaeophorbides, phaeophytins, and their pyro-derivatives), also called phaeo- pigments, are markers indicating physiological status of phytoplankton and decomposition pathways, such as herbivory grazing or bacterial degradation (Mantoura \& Llewellyn 1983, Villanueva \& Hastings 2000). Moreover, since chl $b$ is largely found in higher terrestrial plants and has a shorter half-life than chl $a_{\text {, its }}$ degradation products (phaeophytin $b$ and phaeophorbide $b$ ) can be used to investigate inputs of terrestrial material. Many of the accessory pigments (e.g. fucoxanthin) are specific for certain algal groups and can be used as taxonomic markers (Gieskes \& Kraay 1984, Jeffrey \& Vesk 1997).

Particulate organic matter (POM) within the water column is comprised of all suspended material $>0.45 \mu \mathrm{m}$, and is usually dominated by various types of phytoplankton (including ice algae) and detritus (Sakshaug 2004). Stable isotopes and C:N values may be used to determine the relative importance of ice algae, phytoplankton, and terrestrial sources in the POM (McMahon et al. 2006). C:N values are helpful for differentiating marine and terrestrial organic matter (Redfield et al. 1963, Takahashi et al. 1985, Anderson \& Sarmiento 1994), and provide an indication of potential food quality that is complementary to $\delta^{13} \mathrm{C}$ concentration. In sediments, microbially mediated degradation can directly alter the substrate by isotopic fractionation (Miyake \& Wada 1971, Altabet 1988), such that the data may become more difficult to interpret.

Our study combined pigment and stable isotope analysis, and measurement of elemental composition of POM and sedimentary organic matter to trace the sources and fate of organic matter in the southeast Beaufort Sea. We addressed the following questions: (1) What is the importance of local production for inputs of organic matter to the benthos? (2) Is the Mackenzie River an important source of terrestrial organic material to the entire area? (3) Are the spatial and seasonal variations of organic matter inputs to the benthos affecting benthic activities?

\section{MATERIALS AND METHODS}

Study area and sampling techniques. This study was conducted in the southeast Beaufort Sea (Table 1, Fig. 1) during fall 2003 (20 October to 19 November) and summer 2004 (26 June to 31 July) on board the Canadian Research Icebreaker CCGS 'Amundsen' (see Fig. 2a,b). The study area included the Mackenzie shelf, the Amundsen Gulf, and Franklin Bay. On the shelf area, stations ranged from 42 to $86 \mathrm{~m}$ in water depth, and in the Amundsen Gulf and Franklin Bay, from 167 to $570 \mathrm{~m}$; and Stn 850 was at $1122 \mathrm{~m}$ (Table 1). While the entire area is ice-covered in the winter, the Cape Bathurst polynya opens during spring in the Amundsen Gulf and 


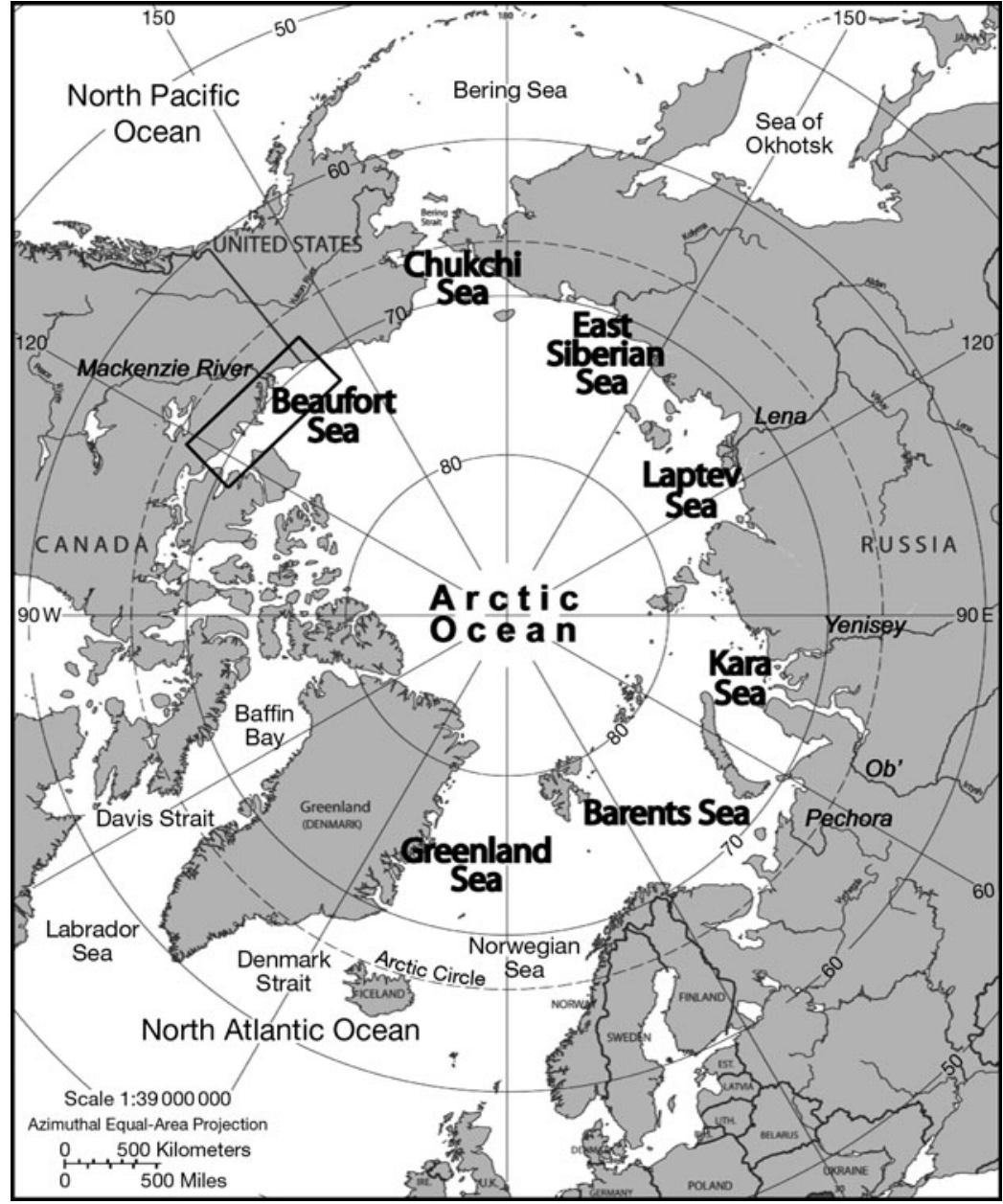

Fig. 1. Major seas and rivers of the Arctic Ocean. The study area (indicated by a rectangle) is situated at the mouth of the Mackenzie River and in the Beaufort Sea. Adapted from the University of Texas Perry-Castaneda Library map collection

0.05); however, Tchl a was significantly correlated with the sedimentary chl a (see Table 2) while the POM chl a concentration was not, suggesting that the sedimentary chl a reflects the entire chl $a$ of the water column and not only at the chlorophyll maximum. For that reason, when comparing sedimentary biomarkers to water column pigments, Tchl a was used instead of POM chl a.

Sediment was sampled by replicate deployments of a box corer $(45 \times 45 \mathrm{~cm})$. Cores were also sampled for estimation of sediment carbon demand, and results are presented in Renaud et al. (2007c). Results are summarized in Table 1. Multiple sub-samples $(5 \mathrm{~cm}$ diameter $\times 10 \mathrm{~cm}$ deep) for sedimentary pigment and stable isotope analysis were taken from each station. The top $2 \mathrm{~cm}$ of sediment were extruded and sliced under diminished light conditions. Each interval slice was divided in 2: half for pigment analysis by fluorometry (Holm-Hansen et al. 1965), and half for pigment analysis by HPLC (Wright et al. 1991, Chen et al. 2001) and stable isotope analysis (Hobson et al. 1995). Both pigment sub-samples were wrapped in foil and frozen directly after slicing in order to avoid pigment degradation.

Fluorometry analysis. Within $2 \mathrm{wk}$, every sub-sample of sediment was analyzed for chloropigment content by fluorometry (Holm-Hansen et al. 1965). The samples were placed in $60 \mathrm{ml}$ cen-

along the continental slope, and by summer, the entire area is usually ice-free. All summer stations were icefree, but during the fall, ice was present at some stations.

In the fall, sediment was collected at 7 stations, and water column samples were collected at 11 stations; in the summer, there were 20 sediment and 11 water column stations (see Fig. 2a,b). To collect POM, $250 \mathrm{ml}$ to 101 of water from the chlorophyll maximum depth (between 10 and $50 \mathrm{~m}$, as determined by an in vivo fluorescence probe attached to the CTD) was filtered onto precombusted Whatman GF/F filters (5 h at $500^{\circ} \mathrm{C}$ ). Six replicate filters for POM analysis were stored at $-20^{\circ} \mathrm{C}$ prior to HPLC and isotope analysis. Since many stations did not exhibit a phytoplankton bloom, the chlorophyll max was sometimes poorly defined. Thus, the total chl a (Tchl a) over the entire water column was also measured by sampling several ( 7 to 11 ) depths and integrating for the entire depth. Comparison of the POM chl a and Tchl a showed a significant correlation $(r=0.8, p<$ trifuge tubes, and $20 \mathrm{ml}$ of $100 \%$ acetone were added. Tubes were stored at $-20^{\circ} \mathrm{C}$ in the dark for $48 \mathrm{~h}$ and shaken periodically. Prior to fluorometer analysis, the sediment was centrifuged $\left(1968 \times g\right.$ for $10 \mathrm{~min}$ at $\left.0^{\circ} \mathrm{C}\right)$. The supernatant was analyzed in a pre-calibrated fluorometer (Turner Designs Model 10-AU) before and after acidification with $5 \% \mathrm{HCl}$, in order to determine the ratio of chl a to total phaeopigments (chl a:phaeo). Due to logistic difficulties, the amount of pigment was determined per volume of wet sediment, not by dry weight; thus the values obtained by fluorometry are presented in $\mathrm{mg} \mathrm{m}^{-2}$ for the first $2 \mathrm{~cm}$ of sediment.

HPLC analysis. POM filters were extracted in $2 \mathrm{ml}$ of $100 \%$ HPLC-grade acetone for 12 to $24 \mathrm{~h}$ (adapted from Parsons et al. 1984). Extracts were filtered through $0.2 \mu \mathrm{m}$ nylon syringe filters. Freeze-dried sediment (1 to $3 \mathrm{~g}$ ) was transferred to a $50 \mathrm{ml}$ polypropylene centrifuge tube to which $8 \mathrm{ml}$ of 80:20 HPLC grade acetone:methanol were added (adapted from Leavitt \& 
Table 1. Station position, water depth, distance to Mackenzie River, and sediment carbon demand (SCD) for stations sampled in this study. SCD of the whole core was determined by Renaud et al. (2007c)

\begin{tabular}{|c|c|c|c|c|c|}
\hline Station & $\begin{array}{l}\text { Latitude } \\
\qquad\left({ }^{\circ} \mathrm{N}\right)\end{array}$ & $\begin{array}{l}\text { Longitude } \\
\quad\left({ }^{\circ} \mathrm{W}\right)\end{array}$ & $\begin{array}{l}\text { Water } \\
\text { depth } \\
(\mathrm{m})\end{array}$ & $\begin{array}{c}\text { Distance } \\
\text { to river } \\
(\mathrm{km})\end{array}$ & $\begin{array}{c}\mathrm{SCD} \\
\left(\mathrm{mmol} \mathrm{C}^{-2} \mathrm{~d}^{-1}\right)\end{array}$ \\
\hline \multicolumn{6}{|l|}{ Fall } \\
\hline 100 & 70.586 & 120.991 & 400 & 511 & 1.5 \\
\hline 124 & 71.399 & 126.796 & 400 & 333 & 1.9 \\
\hline 200 & 70.047 & 126.302 & 234 & 310 & \\
\hline 300 & 70.591 & 127.742 & 50 & 266 & 8 \\
\hline 309 & 71.118 & 125.802 & 420 & 352 & 2.2 \\
\hline 315 & 71.484 & 124.538 & 221 & 409 & \\
\hline 400 & 70.917 & 128.916 & 36 & 240 & \\
\hline 415 & 71.901 & 125.866 & 54 & 390 & \\
\hline 500 & 72.001 & 127.578 & 395 & 349 & 2.3 \\
\hline 709 & 70.951 & 133.752 & 86 & 133 & \\
\hline 718 & 70.171 & 133.538 & 45 & 54 & 3.2 \\
\hline \multicolumn{6}{|l|}{ Summer } \\
\hline 109 & 70.654 & 123.366 & 570 & 425 & \\
\hline 124 & 70.676 & 123.412 & 440 & 424 & \\
\hline 200 & 70.047 & 126.302 & 234 & 310 & 4.9 \\
\hline 212 & 70.766 & 123.879 & 440 & 408 & \\
\hline 215 & 70.974 & 123.416 & 294 & 430 & \\
\hline 309 & 71.118 & 125.802 & 420 & 352 & \\
\hline 315 & 71.484 & 124.538 & 221 & 409 & 2.1 \\
\hline 400 & 70.917 & 128.916 & 36 & 240 & 5.2 \\
\hline 406 & 71.314 & 127.713 & 180 & 300 & 1.8 \\
\hline 409 & 71.506 & 127.089 & 380 & 330 & \\
\hline 415 & 71.901 & 125.866 & 54 & 390 & 4.9 \\
\hline 600 & 71.707 & 130.828 & 330 & 251 & \\
\hline 609 & 70.937 & 130.481 & 44 & 195 & 5.2 \\
\hline 650 & 71.319 & 131.583 & 244 & 200 & 1.3 \\
\hline 709 & 70.935 & 133.797 & 82 & 131 & 2 \\
\hline 718 & 70.170 & 133.535 & 42 & 54 & 4.8 \\
\hline 803 & 70.645 & 135.891 & 241 & 112 & 3.2 \\
\hline 809 & 70.092 & 135.342 & 43 & 51 & \\
\hline 850 & 70.567 & 137.592 & 1122 & 150 & \\
\hline 906 & 70.047 & 138.585 & 271 & 163 & 3.9 \\
\hline 912 & 69.488 & 137.940 & 55 & 141 & 4.3 \\
\hline
\end{tabular}

Hodgson 2001). The mixture was sonicated for $5 \mathrm{~min}$ in an ice bath and extracted in the freezer overnight. Extracts were separated from the sediment by centrifugation $(10 \mathrm{~min}, 537 \times g)$, and $5 \mathrm{ml}$ of the supernatant were filtered through a $0.2 \mu \mathrm{m}$ syringe filter. Extracts were blown to dryness under nitrogen, and then redissolved in $250 \mu \mathrm{l}$ of $90 \%$ acetone.

Quantitative analysis of all pigments was conducted with a Waters HPLC equipped with an online photodiode array (Waters 996 PDA) and a fluorescence detector (Waters 616) with excitation set at $440 \mathrm{~nm}$ and emission at $660 \mathrm{~nm}$. We injected $200 \mu \mathrm{l}$ of each sample through a guard column to a reverse phase Alltech Absorbsphere C18 column (5 $\mu \mathrm{m}$ particle size; $250 \mathrm{~mm} \times 4.6 \mathrm{~mm}$ internal diameter). The 3 -step gradient program was modified after Wright et al. (1991) as described by Chen et al. (2001) for enhancing the separation of phaeopigments.

Identification of pigments was performed by comparing retention time and PDA spectra to standards (DHI Water and Environment). Carotenoids were quantified at $438 \mathrm{~nm}$ on the PDA detector, while chlorophylls and phaeopigments were quantified on the fluorometer. The response factor (RF) was determined for each pigment by a single run of each pigment standard. In the POM, the pigments identified for determining the phytoplankton composition through CHEMTAX were chl $a$, peridinin, $19^{\prime}$ but-fucoxanthin, fucoxanthin, prasinoxanthin, 19'hex-fucoxanthin, alloxanthin, zeaxanthin, chl $b$, dinoxanthin, and chl $c_{2}$. In the sediment, chl $a$, some phaeopigments, and some accessory pigments were identified. Many degradation products of chl $a$ and $b$ can be found in the sediment, but only phaeophorbide $a$ and $b$ and phaeophytin $a$ and $b$ were identified in this study. The accessory pigments identified were fucoxanthin as a marker of diatoms and some haptophytes, 19'but-fucoxanthin and 19'hex-fucoxanthin as markers of haptophytes, alloxanthin as a marker of cryptophytes, prasinoxanthin and chl $b$ as markers of green algae (prasinophytes + chlorophytes), peridinin as a marker of dinoflagellates, and zeaxanthin as a marker of cyanobacteria.

Carbon and nitrogen stable isotope analysis. Stable isotope analysis of POM filters was performed after acidification by the National Hydrology Research Institute in Saskatoon, Saskatchewan, Canada, using the method of Hobson et al. (1995). Frozen sediment samples for stable isotope analysis were dried at $60^{\circ} \mathrm{C}$ overnight. To decalcify sub-samples for carbon analysis, about $2 \mathrm{~g}$ of dry, homogenized sediment were placed in a crucible, to which $2 \mathrm{ml}$ of $1 \mathrm{~N} \mathrm{HCl}$ were added, and then dried overnight. This operation was repeated 3 times, or until the sediment did not show a clear bubbling due to the conversion of carbonate to carbon dioxide gas. The decalcified sediment was used for $\delta^{13} \mathrm{C}$ determinations, and undecalcified sediment was used for $\delta^{15} \mathrm{~N}$ analysis. Stable isotope analysis of sediments was performed by the Environmental Geochemistry Laboratory, Department of Geology, Bates College, Lewiston, Maine, using a ThermoFinnigan Delta V coupled to a Costech EA Conflo III combustion interface. All stable carbon isotope values are reported in delta $(\delta)$ notation, in units of per mille $(\%)$, where $\delta=$ $\left[\left(\mathrm{R}_{\text {sample }} / \mathrm{R}_{\text {standard }}\right)-1\right] \times 1000 . \mathrm{R}={ }^{13} \mathrm{C} /{ }^{12} \mathrm{C}$ and ${ }^{15} \mathrm{~N} /{ }^{14} \mathrm{~N}$, and the standards are Vienna Peedee belemnite (VPDB) and air for carbon and nitrogen, respectively. The reproducibility on the bulk sediment was $\pm 0.2 \%$, as determined by the standard deviation of multiple analyses.

CHEMTAX and statistical treatment. The contributions of the 6 major algal groups (diatoms, hapto- 
phytes, cryptophytes, green algae, dinoflagellates, and cyanobacteria) were estimated from the pigment ratios determined by HPLC at the water chlorophyll maximum depth, using the CHEMTAX program and initial ratios of Mackey et al. (1996). The use of CHEMTAX as an estimation of the algal groups from pigments is controversial, as it is often difficult to establish accurate pigment ratios, and these may vary depending upon environmental conditions; however, the results obtained with CHEMTAX followed the tendency observed in the raw pigments ratios, i.e. high percentage of dinoflagellates when abundant peridinin was found (see above for the main pigment markers of taxonomic groups). Moreover, the relevance of CHEMTAX for estimating major algal group contributions in the present study was confirmed by comparison to microscopic algal counts (S. Brugel pers. obs.).

Seasonal differences between summer and fall and spatial differences between the gulf and the Mackenzie shelf were analyzed by a $t$-test when the data were normal and variances were equal, and by a MannWhitney Rank Sum test (MW test) when the data failed normality and equal-variance tests. It is important to note that the stations studied in summer and in fall were not always the same, but are still assigned to either shelf or gulf areas. This could introduce a confusing bias while trying to make seasonal comparisons (see 'Discussion'). Linear relationships between environmental factors (depth, distance to river, Tchl a), sediment oxygen demand (data from Renaud et al. 2007c), and biomarkers were analyzed by Pearson's productmoment correlation. Correlation analyses, MW tests, and $t$-tests were performed using SigmaStat 3.5 (2006 Systat Software).

\section{RESULTS}

\section{Phytoplankton species and water column isotopes}

Chl a integrated over the entire water column (Tchl a) is presented in Fig. 2c,d. Values were higher in the summer than during the fall (MW test, $\mathrm{p}<0.05$ ). Tchl a values were higher closer to the coast, particularly near the Mackenzie River delta, and may reflect an increase in primary productivity associated with increased nutrient delivery to the nearshore zone. Analysis of pigment distributions using CHEMTAX indicated seasonal and spatial differences in phytoplankton distributions (Fig. 2e,f). In the summer, diatoms dominate on the shelf region (mean $70 \pm 11 \%$ ), whereas smaller cells, such as haptophytes and green algae, are more abundant in the gulf (total $83 \pm 15 \%$ ). In the fall, diatoms decreased significantly (mean for all areas $15 \pm 10 \%$, $t$-test, $p<0.05$ ); haptophytes and green algae dominated (both combined represent mean $80 \pm 17 \%$ ).

The $\mathrm{C}: \mathrm{N}$ ratio in POM in the fall was higher than in the summer ( $t$-test, $\mathrm{p}<0.05)$. In the fall, $\mathrm{C}: \mathrm{N}$ values ranged between 9.3 at Stn 718 and 17.1 at Stn 309, and were higher in the gulf than on the shelf, while most of summer C:N data were between 6.7 and 9.5 . $\delta^{13} \mathrm{C}$ values in POM were significantly lower in the fall than in the summer $(t$-test, $\mathrm{p}<0.05) . \delta^{13} \mathrm{C}$ varied from $-26.6 \%$ (Stn 410 ) to $-28.5 \%$ (Stn 718) in the fall, and from $-21.0 \%$ (Stn 912) to -26.8 (Stn 200) in the summer. $\delta^{15} \mathrm{~N}$ values of POM varied from $0 \%$ o (Stn 100 ) to $4 \%$ (Stn 709) in the gulf and were more variable and more enriched (higher $\delta^{15} \mathrm{~N}$ value) along the shelf, particularly in the summer (Fig. 3 and see Fig. 6a).

\section{Sedimentary pigments and isotopes}

Sedimentary chl a values as determined by fluorometry and by HPLC were significantly correlated $(\mathrm{r}=0.8$, $\mathrm{p}<0.05)$. Sedimentary chl a determined by HPLC ranged from $<0.01$ in the Amundsen Gulf to a maximum of $3 \mu \mathrm{g} \mathrm{g}^{-1}$ dry weight on the shelf. Sedimentary chl a determined by fluorometry ranged from 0.16 to $19.52 \mathrm{mg} \mathrm{m}^{-2}$ (Fig. 4c,d). Highest sedimentary chl a values were found close to the Mackenzie River delta and in shallow areas. For both shelf and gulf areas, significant differences were not found between the fall and the summer. However, the difference between the gulf and the shelf was significant in the summer (MW test, $\mathrm{p}<0.05$ ) and showed a similar tendency in the fall (MW test, $\mathrm{p}=0.05$ ). The chl a:phaeo ratio (Fig. $4 \mathrm{a}, \mathrm{b}$ ), an indicator of the freshness of the organic matter reaching the benthos, showed similar results for the summer, with higher ratios (fresher material) on the shelf (MW test, $\mathrm{p}<0.05)$. Sedimentary accessory pigments varied spatially and seasonally (Fig. 4e,f). In the summer, sedimentary fucoxanthin and chl $b$ were the most abundant accessory pigments on the continental shelf and in the gulf, respectively, while in the fall, the pigment composition was more heterogeneous and indicated a substantial contribution from other taxonomic groups on the sediment surface, including dinoflagellates and small cells (haptophytes and green algae).

No significant seasonal differences were observed (all $\mathrm{p}>0.05$ ) between fall and summer for sedimentary isotopes (Figs. 5 \& 6b); however, significant spatial differences in both $\delta^{15} \mathrm{~N}$ and $\delta^{13} \mathrm{C}$ values were observed between the Amundsen Gulf and the shelf area (MW tests, $\mathrm{p}<0.05)$. Both $\delta^{15} \mathrm{~N}$ and $\delta^{13} \mathrm{C}$ were highest in the gulf area. In the fall, the highest values were observed at Stn $100\left(\delta^{15} \mathrm{~N} 6.8 \%\right.$; $\delta^{13} \mathrm{C}-22.8 \%$ ), and in the summer, at $\operatorname{Stn} 212\left(\delta^{15} \mathrm{~N} 6.7 \%\right.$; $\delta^{13} \mathrm{C}-21.1 \%$ o). On the shelf, the values were lower. In the fall, the lowest was 

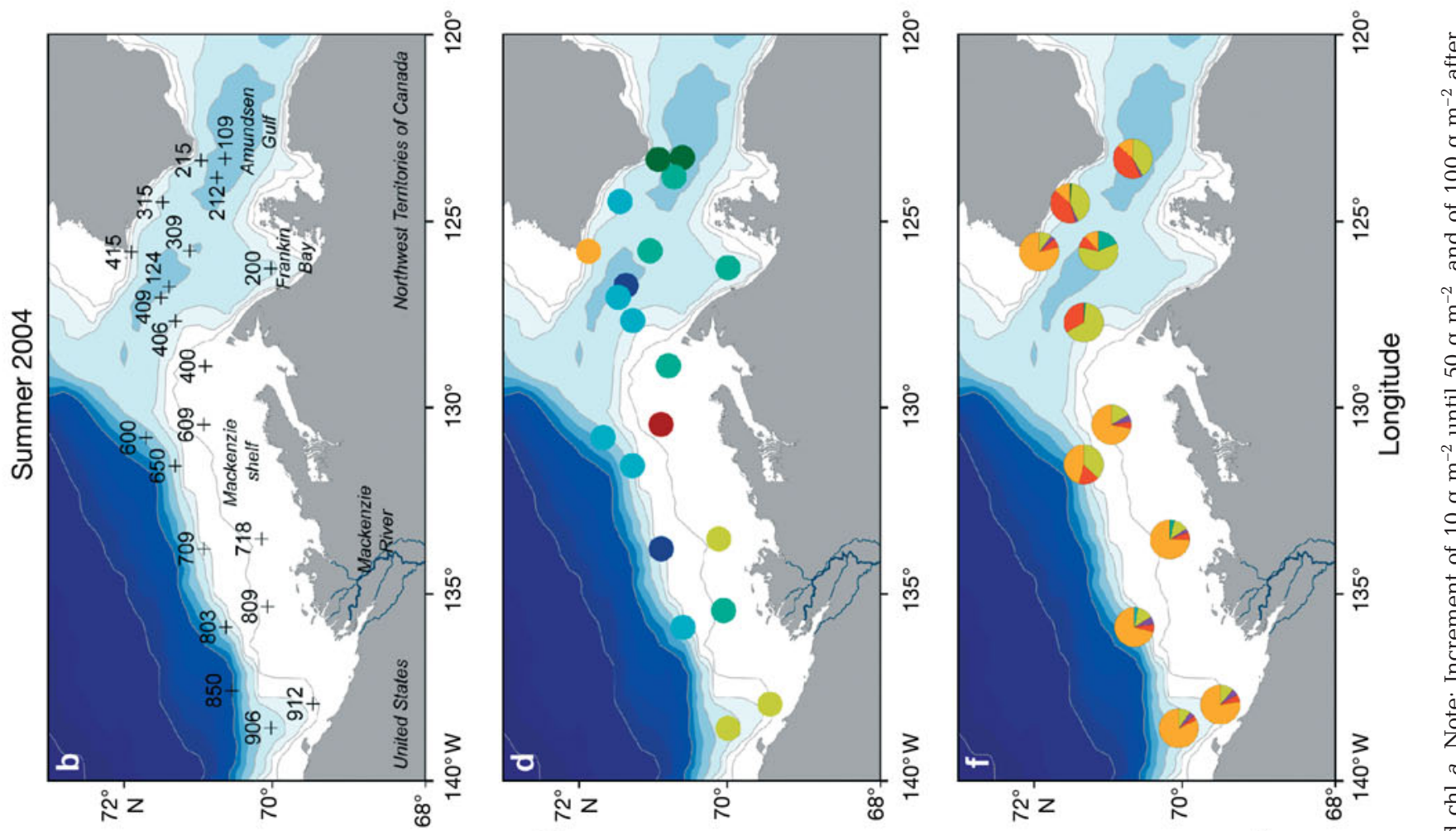

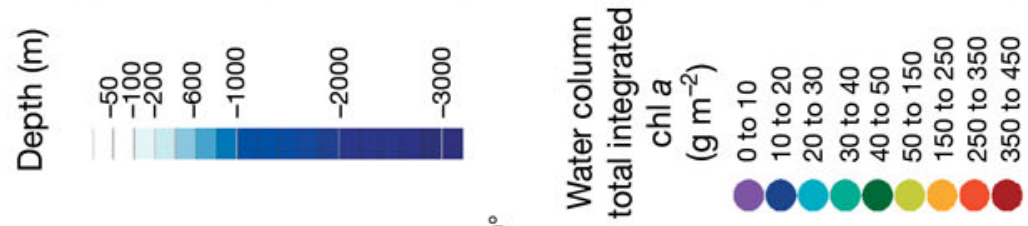
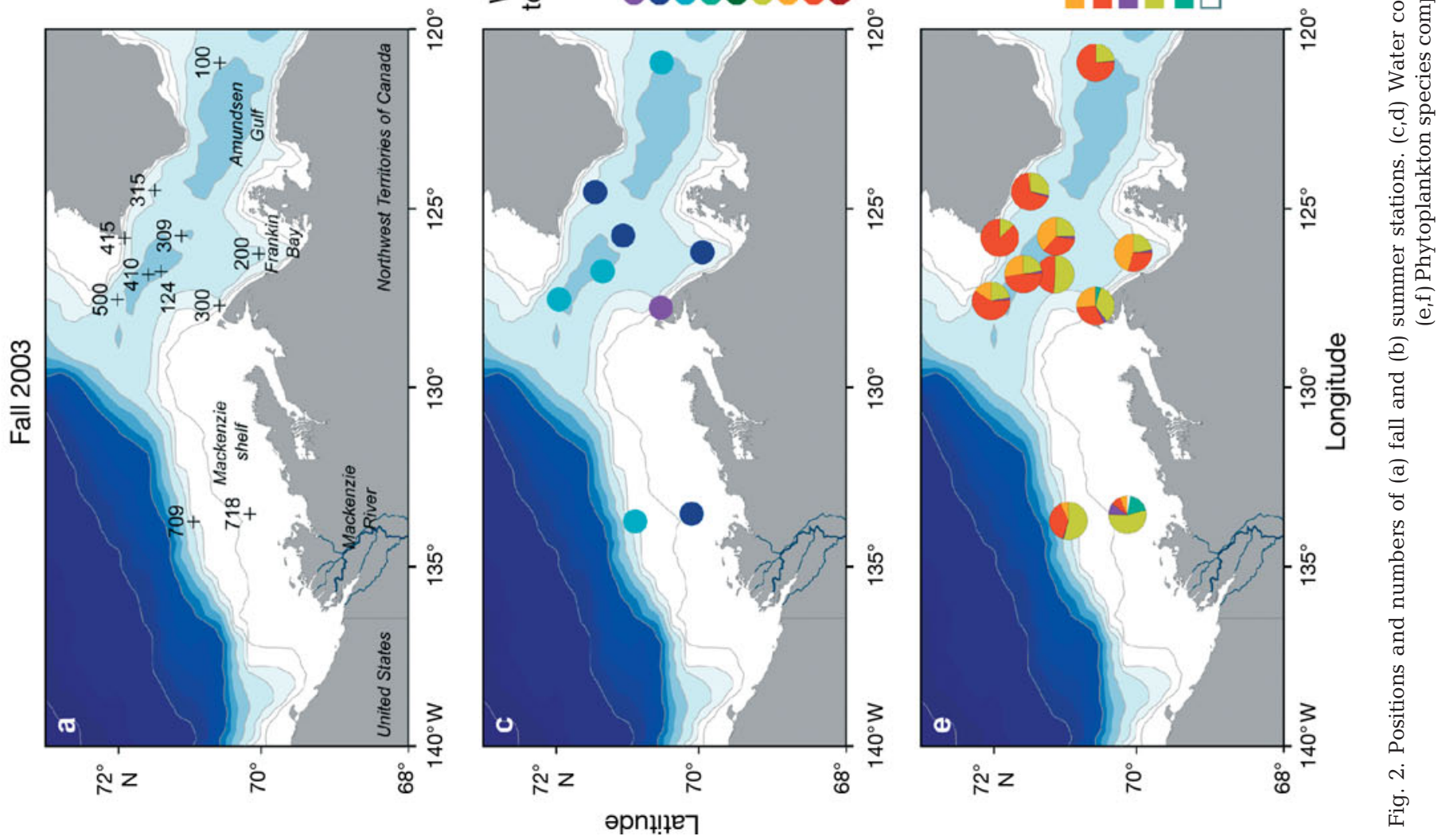

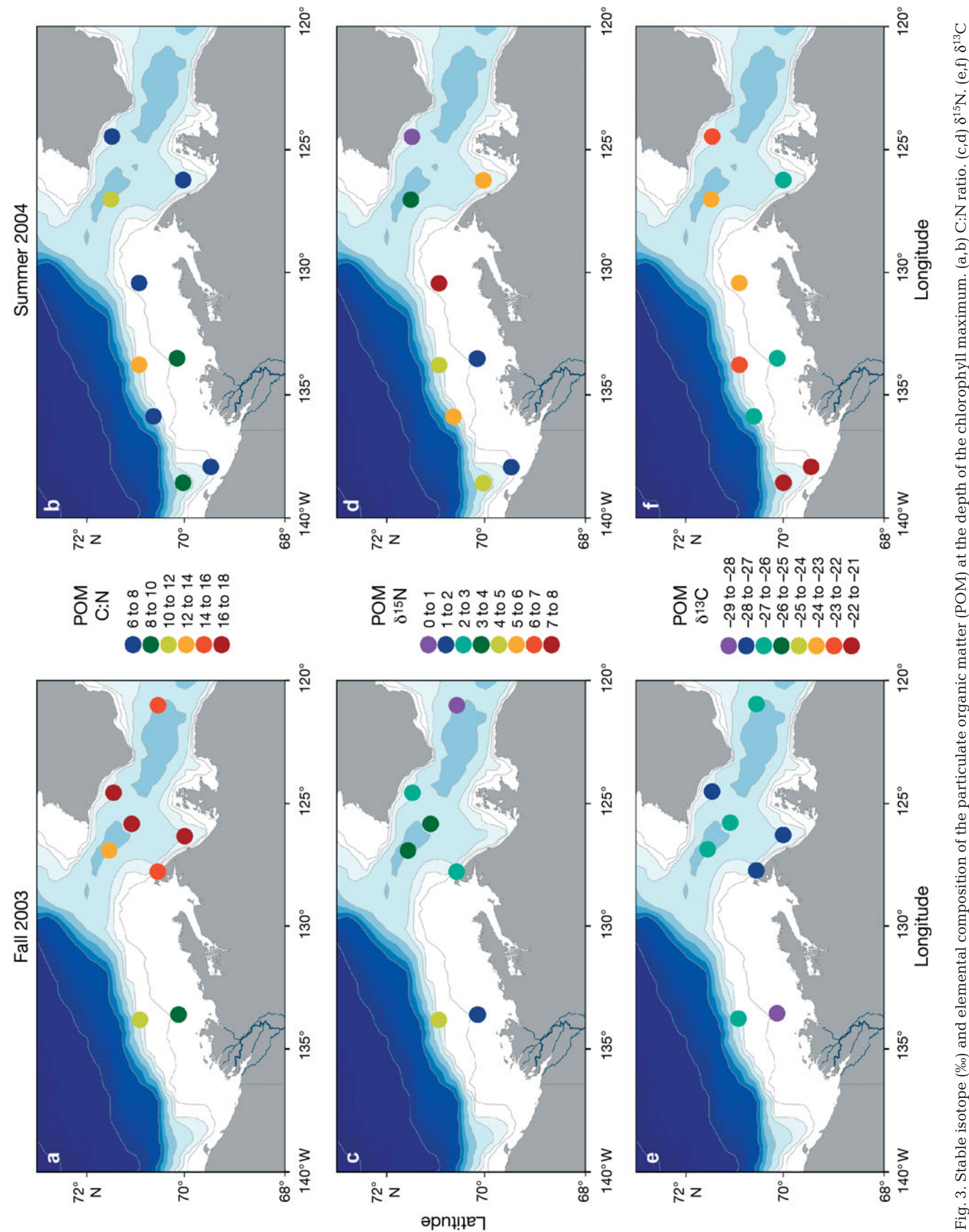

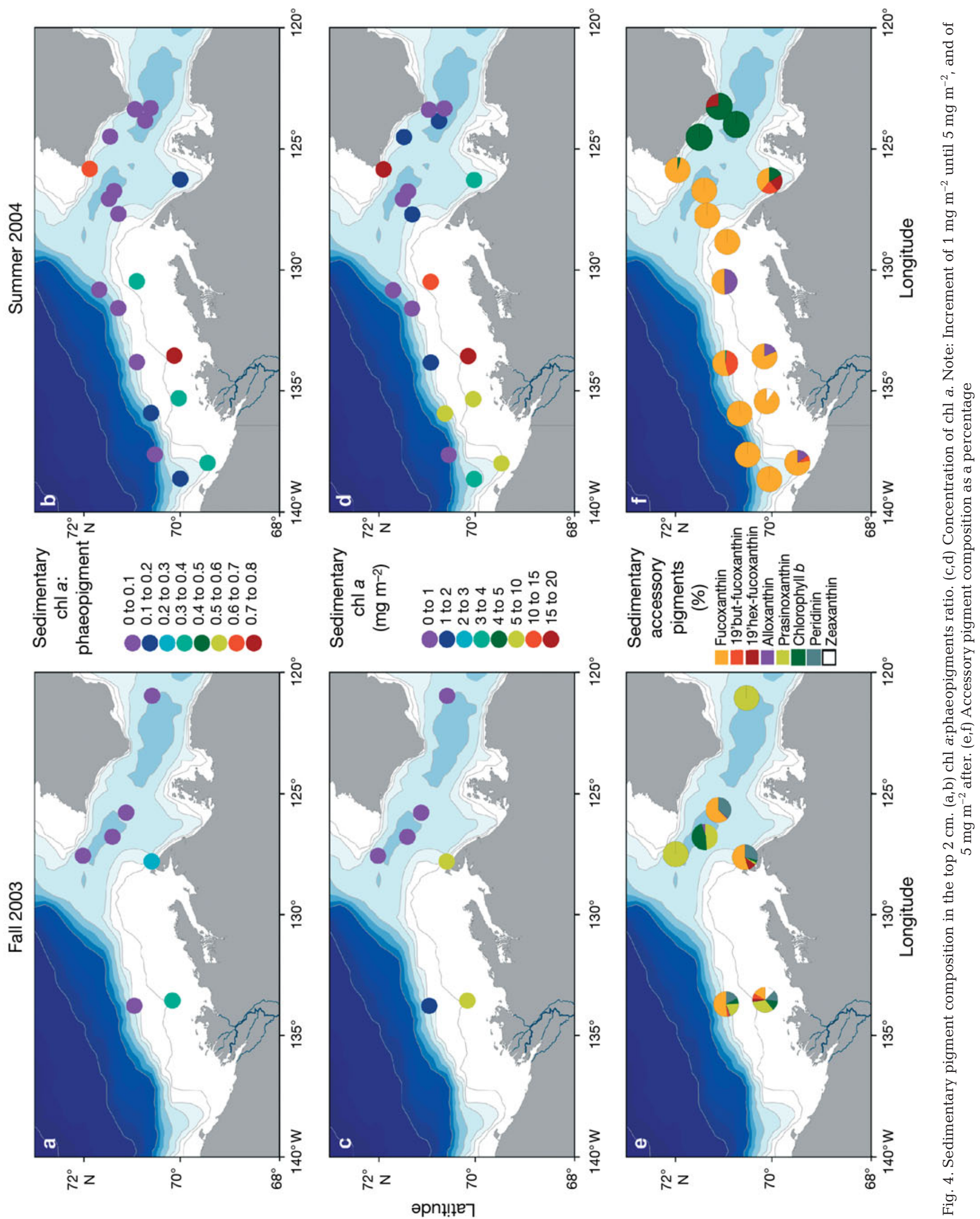

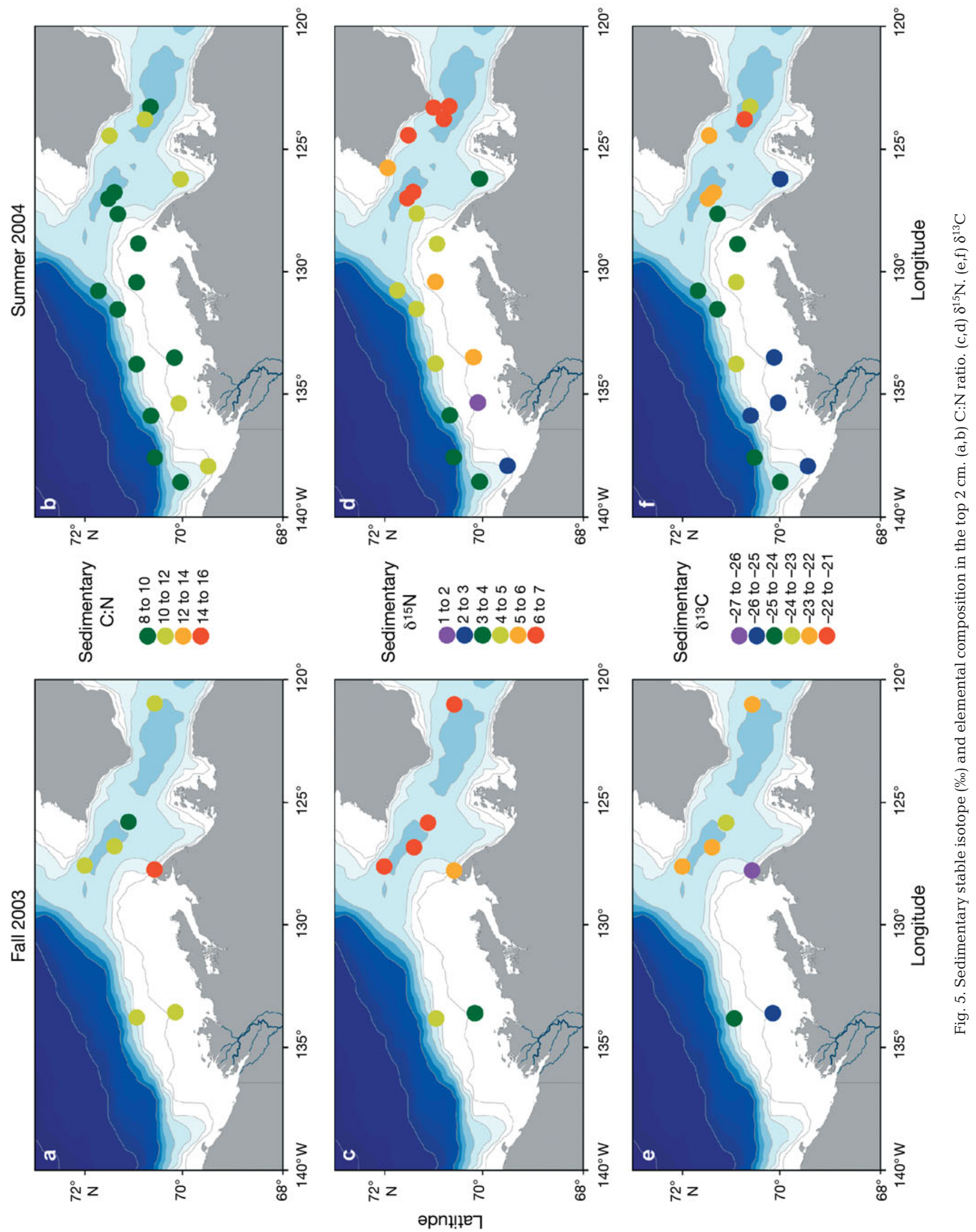
Table 2. Correlation between environmental factors (water depth, distance to river, water column total integrated chl $a$ [Tchl a], and sediment carbon demand, SCD) and sedimentary biomarkers during fall 2003 and summer 2004. Significant correlations $(\mathrm{p}<0.05)$ are indicated in bold. SCD data from Renaud et al. $(2007 \mathrm{c})$

\begin{tabular}{|c|c|c|c|c|c|c|c|c|}
\hline & & $\delta^{15} \mathrm{~N}$ & $\delta^{13} \mathrm{C}$ & Chl a:Phaeo & $\mathrm{Chl} \mathrm{a}$ & Phaeophorbide $a$ & Phaeophytin $a$ & Chl $b$ degraded \\
\hline Depth & $\begin{array}{l}\text { Fall } \\
\text { Summer }\end{array}$ & $\begin{array}{l}\mathbf{0 . 9 5} \\
0.02\end{array}$ & $\begin{array}{l}\mathbf{0 . 9 4} \\
0.05\end{array}$ & $\begin{array}{l}-0.77 \\
-0.50\end{array}$ & $\begin{array}{l}-0.82 \\
-0.52\end{array}$ & $\begin{array}{r}0.56 \\
-0.43\end{array}$ & $\begin{array}{c}-0.2 \\
0.38\end{array}$ & $\begin{array}{l}-\mathbf{0 . 8 2} \\
-0.01\end{array}$ \\
\hline Distance to river & $\begin{array}{l}\text { Fall } \\
\text { Summer }\end{array}$ & $\begin{array}{l}0.69 \\
\mathbf{0 . 7 9}\end{array}$ & $\begin{array}{l}0.93 \\
0.78\end{array}$ & $\begin{array}{l}-0.68 \\
-0.34\end{array}$ & $\begin{array}{l}-0.6 \\
-0.29\end{array}$ & $\begin{array}{r}0.08 \\
-0.17\end{array}$ & $\begin{array}{c}-0.56 \\
0\end{array}$ & $\begin{array}{r}-\mathbf{0 . 9 2} \\
0.07\end{array}$ \\
\hline Tchl a & $\begin{array}{l}\text { Fall } \\
\text { Summer }\end{array}$ & $\begin{array}{l}\mathbf{0 . 7 9} \\
0.03\end{array}$ & $\begin{array}{r}\mathbf{0 . 9 8} \\
-0.06\end{array}$ & $\begin{array}{c}-0.63 \\
0.36\end{array}$ & $\begin{array}{r}-0.79 \\
0.63\end{array}$ & $\begin{array}{l}0.2 \\
0.42\end{array}$ & $\begin{array}{l}-0.03 \\
-0.23\end{array}$ & $\begin{array}{r}-\mathbf{0 . 3 2} \\
0.01\end{array}$ \\
\hline $\mathrm{SCD}$ & $\begin{array}{l}\text { Fall } \\
\text { Summer }\end{array}$ & $\begin{array}{l}-\mathbf{0 . 8 9} \\
-0.23\end{array}$ & $\begin{array}{r}-\mathbf{0 . 8 9} \\
0.09\end{array}$ & $\begin{array}{l}0.52 \\
\mathbf{0 . 7 0}\end{array}$ & $\begin{array}{l}0.78 \\
0.73\end{array}$ & $\begin{array}{l}-0.68 \\
-0.17\end{array}$ & $\begin{array}{r}-0.19 \\
0.29\end{array}$ & $\begin{array}{l}0.23 \\
0.24\end{array}$ \\
\hline
\end{tabular}

observed at Stn $300\left(\delta^{15} \mathrm{~N} 2.1 \% ; \delta^{13} \mathrm{C}\right.$ $-26.2 \%)$, and in the summer at Stn 809 $\left(\delta^{15} \mathrm{~N} \quad 1.9 \% ; \quad \delta^{13} \mathrm{C}-25.8 \%\right)$. The C:N ratio did not show clear seasonal or spatial variation. The minimum (8.5) was observed at Stn 124 in the summer and the maximum (15) at Stn 300 in the fall.

\section{Environmental factors and biomarker correlations}

The percentage of nitrogen in POM samples showed a significant inverse correlation with the distance to the river mouth during the fall $(\mathrm{r}=-0.93, \mathrm{p}<0.05)$, but no other significant relationship was found between the depth and distance to river and either POM, isotopes, or Tchl $a$. In the fall, the percentage of haptophytes was significantly correlated with the distance to the river $(r=0.86, p<0.05)$, and the percentage of green algae was significantly inversely correlated $(\mathrm{r}=-0.78, \mathrm{p}<$ $0.05)$ with the distance to the river. The $\delta^{15} \mathrm{~N}$ and $\delta^{13} \mathrm{C}$ and C:N values of POM varied seasonally (Fig. 6a). Fall stations had a more terrestrial (i.e. depleted) signature, while summer stations had a more marine (i.e. enriched) and mixed signature.

Although environmental factors did not seem to influence summer POM constituents, correlations between depth, distance to the river mouth, and total water column chl a with sedimentary biomarkers (Table 2) showed the importance of these factors for sediment isotopes and pigments for both seasons.
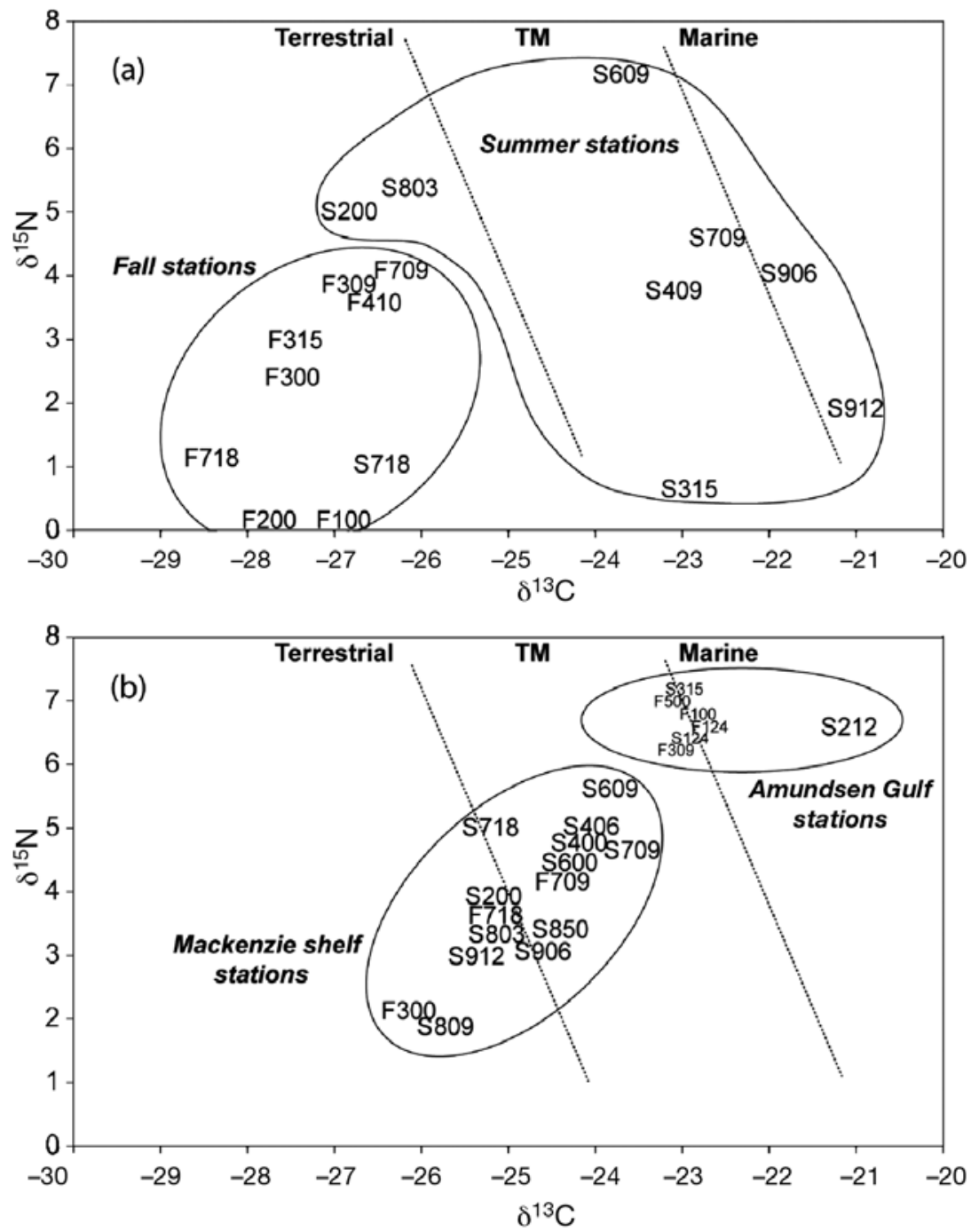

Fig. 6. Stable isotope composition (\%) in (a) the particulate organic matter at the depth of chlorophyll max and (b) the sediment. Dashed lines represent Parsons' delimiting lines (Parsons et al. 1989) for separating terrestrial (T) from marine $(\mathrm{M})$ origin. TM represents an area of mixing between terrestrial and marine origin 
The amount of sedimentary chl $a$ and the chl a:phaeo ratio were always significantly inversely correlated with depth (Table 2). In the fall, depth was significantly positively correlated with the sedimentary carbon and nitrogen isotopes; however, there was no correlation in the summer. In the fall, degraded chl $b$ (phaeophytin and phaeophorbide $b$ ) was inversely correlated with depth and distance to the river. During the summer, total phaeopigments correlated significantly with phaeophorbide $a(r=0.64, p<0.05)$, while in the gulf area, total phaeopigments correlated with phaeophytin a $(\mathrm{r}=$ $0.61, \mathrm{p}<0.05)$.

In the summer, sedimentary $\delta^{13} \mathrm{C}$ and $\delta^{15} \mathrm{~N}$ values were significantly correlated with the distance to the river mouth, while the correlation was only significant for $\delta^{13} \mathrm{C}$ values in the fall. Geographical differences in sediment isotopes were also found when plotting $\delta^{13} \mathrm{C}$ with $\delta^{15} \mathrm{~N}$ values (Fig. 6b).

\section{DISCUSSION}

The use of multiple biomarkers for both water column and sediment analysis in the southeast Beaufort Sea allowed delineation of sources of carbon and confirmed the strength of pelagic-benthic coupling. The approach also allowed an understanding of the relative importance of time and space for both the sources of organic matter and its fate. Local water-column inputs to the benthos were also identified as well as the geographical differences based on the Mackenzie River influence, and how changes in organic matter inputs to the sea floor can impact the benthos.

\section{Importance of local water-column inputs}

The significant positive correlation between Tchl a and sedimentary chl $a$ in the summer $(r=0.6, p<0.05)$ suggests that local primary production contributes significantly to the inputs of fresh organic matter to the benthos in all areas. The negative correlation in the fall, which was also found by Bessière et al. (2007), is harder to explain, and might be the result of the very small range of data observed for both Tchl a and sedimentary chl a. Further investigation into this correlation would be needed in the case of low values such as those observed in the fall. The southeast Beaufort Sea is thought to be oligotrophic (Carmack et al. 2004, Walsh et al. 2005), and the inputs of fresh organic matter to the benthos are minimal. On the shelf area, our sedimentary chl a averaged $1.7 \pm 1 \mu \mathrm{g} \mathrm{g}^{-1}$ and was similar to values found in the Bering Sea (Pirtle-Levy et al. in press). In the gulf area, the average $(0.05 \pm 0.07 \mu \mathrm{g}$ $\mathrm{g}^{-1}$ ) showed similar values to the Northeast Water and
North Water polynyas (Ambrose \& Renaud 1997, Grant et al. 2002, respectively). These values are higher than in the deep central Arctic Ocean (Clough et al. 1997, Soltwedel \& Schewe 1997), but lower than in more productive systems such as in the Bering and the Barents Seas for similar depths (Cooper et al. 2005, Morata \& Renaud 2008, respectively) and emphasize the importance of water column productivity for sedimentary chl a in Arctic ecosystems.

Not only has the total chl $a$ in the water column been shown to determine the sedimentary chl $a$, but the composition of phytoplankton was also reflected in the sedimentary pigment composition in other Arctic ecosystems (Morata \& Renaud 2008, Pirtle-Levy et al. in press). In our study, the importance of diatoms in the summer was reflected in the sediment by the importance of fucoxanthin, while in the fall, pigments of smaller cells (haptophytes, prasinophytes) were found in the sediment. Phytoplankton observations in sediment traps in Franklin Bay also showed a dominance of small cells (coccolithophores and flagellates) in the fall and a higher abundance of diatoms in the summer (Forest et al. 2008). It is commonly thought that picoplankton is recycled within the food web and only larger phytoplankton is exported. Recently, Richardson \& Jackson (2007) suggested that picoplankton, despite their small size, can play an important role in inputs of organic matter to the equatorial Pacific benthos. Traditionally, the Arctic marine production has been thought to be dominated by large phytoplankton (von Quillfeldt 1997); however, recent studies have shown that picophytoplankton can play an important role in late summer (Not et al. 2005, Lovejoy et al. 2006), including in the Beaufort Sea (Lovejoy et al. 2007). These small cells seem to sink relatively fast, probably while aggregated or associated with larger cells, as suggested by Richardson \& Jackson (2007), and represent a source of inputs of organic matter to the benthos in the fall.

In the Amundsen Gulf area, the importance of green algae in the water column is reflected in the sediment by the presence of chl $b$. Arctic waters tend to have high amounts of green algae (Suzuki et al. 2002, Not et al. 2005, Morata et al. 2008), but green algae are also found in freshwaters (see discussion about river inputs below). The absence of chl $b$ between the Mackenzie River and the gulf area (mainly fucoxanthin is found as an accessory pigment on the shelf), and the strong signal of chl $b$ in the gulf is most likely to indicate greater importance of Arctic water in this region than on the shelf.

Sedimentary fucoxanthin was found broadly in the shelf area in the summer. Diatoms are important primary producers in the Arctic for both phytoplankton and ice algae (von Quillfeldt 2000 and references 
therein). Ice algal diatoms have been previously found in Arctic sediment (Sancetta 1981, Cremer 1999, Polyakova 2003, Ambrose et al. 2005) and were also found at Stn 200, studied over the winter/spring (N. Morata pers. obs.). While chlorophylls are in general more labile and have shorter half lives (few weeks in the Arctic; Graf et al. 1995), carotenoids, such as fucoxanthin, can be very persistent in the sediment (Buchaca \& Catalan 2007). Sedimentary fucoxanthin found in the summer could reflect remaining inputs from the spring ice-associated algae. Ice algae are quickly processed by benthic fauna (McMahon et al. 2006, Renaud et al. 2007a). However, resting cells of diatoms can remain in the sediment from months to years (McQuoid et al. 2002), and Smith et al. (2006) suggested the idea of a 'foodbank' in Antarctica, where phytopigments can be stored and remain available through the year. The high amounts of sedimentary fucoxanthin in the summer may indicate that, while benthic communities quickly utilize newly deposited ice algae, some phytopigments remain for a longer period. These values of high amounts of sedimentary fucoxanthin raise questions similar to those of PirtleLevy et al. (in press), who also found significant concentrations of fucoxanthin in the sediment of the Bering Sea. Alternatively, the POM data (Tchl $a, \delta^{13} \mathrm{C}$, $\mathrm{C}: \mathrm{N})$ imply rapid rates of primary production in the summer months on the shelf, which might increase the flux of fucoxanthin into the sediment record. Although it is impossible to differentiate ice algae diatoms from phytoplankton diatoms using pigment analysis, it would be interesting in the future to assess the importance of inputs from ice algae in the sediment by other techniques such as direct cell identification and counting or lipid biomarker analysis (McMahon et al. 2006).

While both sedimentary chl a and phaeopigments reflect inputs of fresh organic matter, the presence of phaeopigments also indicates degradation processes (Mantoura \& Llewellyn 1983, Villanueva \& Hastings 2000) since phaeophorbide $a$ is a marker for herbivore digestion (Bianchi et al. 1988), and phaeophytin a can result from microzooplankton or microbenthos grazing (Bianchi et al. 1988, Verity \& Vernet 1992), bacterial degradation (Leavitt \& Carpenter 1990), or cell senescence (Louda et al. 1998). During the summer, intact fecal pellets of large herbivorous copepods and appendicularians were found in sediment traps, while in the fall, pellets were more degraded (Forest et al. 2007). The correlation of total sedimentary phaeopigments with sedimentary phaeophorbide $a$ in the summer (Table 2) underlines the importance of macro- and mesozooplankton grazing as a main degradation factor of material reaching the benthos; however, in the fall, the very low chl a:phaeo ratios suggested that the material reaching the benthos was highly processed, and it is difficult to relate $\mathrm{chl}$ a degradation products to their sources. Spatially, for both seasons, the total phaeopigments in the gulf area were correlated with phaeophytin a (Table 2), highlighting complex degradation processes, since phaeophytin a can be created by microbial degradation, grazing, and cell senescence. On the shelf area, no clear correlation was found.

The significant correlation between phaeopigments and phaeophytin $a$, the lowest chl a:phaeo ratios, and the enriched $\delta^{15} \mathrm{~N}$ and $\delta^{13} \mathrm{C}$ values suggest that in the gulf area, material reaching the sediment has been heavily degraded, especially by microbial degradation. Products from microbial activity are an important source of organic matter to the benthos 4 to 11 mo after the phytoplankton bloom in the Bering Sea (Lovvorn et al. 2005), and enhanced microbial degradation has been observed in the polynya (Lovejoy et al. 2002, Sherr et al. 2003, Wassmann et al. 2006). The presence of a polynya, where phytoplankton blooms usually occur earlier than in the rest of the system, could explain an enhanced bacterial degradation in this area, but the greater water depth could also be a factor, as observed by Grebmeier \& Barry (1991). Sedimentary chl a is inversely correlated with depth (Table 2, Ambrose \& Renaud 1995), suggesting that over a deeper water column, material has more time to be degraded and recycled by bacteria, and thus a smaller, and more degraded, fraction of the overlying production reaches the seafloor. However, it remains impossible to determine the relative importance of these 2 mechanisms.

\section{River influence}

To determine the origin of materials in the sediment of the Beaufort Sea, Parsons et al. (1989) determined the stable isotope composition $\left(\delta^{15} \mathrm{~N}\right.$ and $\left.\delta^{13} \mathrm{C}\right)$ and delimited approximate maximum values for marine and terrestrial sources of organic material. These amounts are represented in Fig. 6. For the POM, the origin differed between seasons (fall was more terrestrial, summer was more marine), while in the sediment, the spatial position seemed to be a more important factor in determining the matter origin, since the gulf area had a more marine signature and the shelf area had a more terrestrial signature. Certainly, the entire study region can receive both terrestrial and marine carbon, and preferential degradation of the more labile marine source may be partly responsible for the reduced marine signature in gulf and summer samples. However, the general patterns reflect well the seasonal and spatial patterns in extent of the Mackenzie plume, and supporting data are discussed below. 
The autochthonous marine signature of the POM in the summer was also confirmed by $\mathrm{C}: \mathrm{N}$ ratios of 6 to 7 (Fig. 3a), which are typical of marine phytoplankton (Redfield et al. 1963, Daly et al. 1999). It is important to note that the POM samples were sampled at the chl $a$ max determined by the CTD, between 10 and $50 \mathrm{~m}$; however, at some stations, elevated levels of chl a were also observed in the surface waters (S. Brugel pers. obs.), where the water properties over the first $5 \mathrm{~m}$ showed a lower salinity typical of the Mackenzie River. Previous studies have reported the spread of the Mackenzie plume across the shelf region as a shallow lens, especially later in the summer and fall (Carmack \& Macdonald 2002, Carmack et al. 2004), but this seemed to have a low direct influence on the composition of deeper POM (Fig. 3); however, nutrients delivered by the Mackenzie River might be stimulating primary productivity in the nearshore zone. Previous studies have suggested that although a heterotrophic food web based on riverine organic carbon exists near the Mackenzie River mouth, the offshore community is more marine/oceanic (Parsons et al. 1988, O'Brien et al. 2006). Although the stations studied in summer and fall were different, which, as mentioned previously, might lead to a bias during comparison, POM had a more terrigenous signature in the fall, as also suggested by other POM biomarker studies (Yunker et al. 1995) and sediment trap studies (O'Brien et al. 2006, Forest et al. 2007) and the presence of allochthonous bacteria on the shelf (Wells et al. 2006).

While the river influence on the POM was seasonal, with maximal direct influence in the fall, sedimentary isotope values showed more of a spatial difference between the gulf and the shelf (Fig. 6b). The higher $\delta^{15} \mathrm{~N}$ and $\delta^{13} \mathrm{C}$ values suggested that during the summer, in the gulf area (farthest from the river), material reaching the benthos is more marine and/or degraded. Conversely, the shelf had a more terrestrial signature (terrestrial $\delta^{13} \mathrm{C}$ values of -26.5 to $-27 \%$ for the Beaufort area; Naidu et al. 1993, Goñi et al. 2000). The difference in isotopic signature between the Mackenzie shelf and the Amundsen Gulf was confirmed when plotting $\delta^{13} \mathrm{C}$ and $\delta^{15} \mathrm{~N}$ values for sediments (Fig. 6b), highlighting the geographic position as the main factor influencing sedimentary stable isotope values.

Although stable isotope measurements did not show seasonal variations, chl $b$ degradation products (phaeophytin $b$ and phaeophorbide $b$ ) were more abundant in the fall. Chl $b$ occurs mainly in green algae and terrestrial plants (Kowalewska 2005) and is less stable than chl a (Kowalewska \& Szymczak-Zyla 2001); however, degradation products of chlorophylls are usually very persistent in sediment records (Scheer 1991). Freshwater green algae have been used as a marker of river runoff in the Beaufort, Laptev, and Kara Seas (Mat- thiessen et al. 2000), and high sedimentary chl $b$ contents have been attributed to the intensive influence of riverine fresh water (Kowalewska et al. 1996, Matthiessen et al. 2000). In the fall, the high levels of chl $b$ degradation products and the strong negative correlation of chl $b$ degradation products with distance from the river suggest that, as for the POM, the influence of degraded material from the Mackenzie River is high, especially on the shelf; however, this material probably represents a small portion of the total organic matter present in the sediment, and this signal is lost when studying stable isotopes in the bulk sediment. Sedimentary stable isotopes values integrate signals at a longer time scale and showed clear spatial variations, but no seasonal variations.

To date, our knowledge of the influence of Arctic rivers on POM and sedimentary stable isotope composition has been based on rivers such as the Lena River influencing the Laptev Sea (Rachol \& Hubberten 1999), and the $\mathrm{Ob}$ and Yenisei Rivers influencing the Kara Sea (Fahl et al. 2003). These studies in the Arctic, as in temperate estuaries (McCallister et al. 2004, Hoffman \& Bronk 2006), found depletion in ${ }^{13} \mathrm{C}$ next to the river mouth, implying high amounts of terrigenous detrital input, while enriched ${ }^{13} \mathrm{C}$ values were found in regions less influenced by rivers such as the Chukchi, Bering, and Barents Seas (Naidu et al. 1993, Dunton et al. 2006, Tamelander et al. 2006). Although sedimentary isotopes might not by themselves reflect changes in organic matter origin on a short time scale, combined with sedimentary pigment, they should allow the tracking of changing influences of the Mackenzie River on the Beaufort Sea.

\section{Seasonal and spatial variations in the inputs of organic matter to the benthos}

Benthic community response to inputs of fresh phytodetritus is rapid (Renaud et al. 2007a), and sediment carbon demand (SCD) is correlated with sedimentary chl a (Clough et al. 2005, Renaud et al. 2007c, 2008). Our study shows that not only the sedimentary chl a correlates with SCD, but also the chl a:phaeo ratio, an indicator of the 'freshness' of the organic matter (Table 2). Moreover, the percentage of organic carbon in the sediment $\left(\% \mathrm{C}_{i} \mathrm{~N}\right.$. Morata unpubl. data) is significantly correlated with SCD in the summer, while stable isotope measurements correlate with SCD in the fall. Stable isotope measurements of the bulk sediment relate the total contents of organic matter in sediment, not only the fresh inputs as pigments. This suggests that in the summer, benthic activities depend on the arrival of fresh organic matter, characterized by a high amount of chl $a$, high chl a:phaeo ratio, and high \% $C_{\text {, }}$ 
while in the fall, since material reaching the sediment is more degraded and less important, benthic activities depend more on the bulk of organic matter. Inputs of phytodetritus also have an impact on the meiofauna in the southeast Beaufort Sea (Bessière et al. 2007), where highest meiofauna densities in the summer on the Mackenzie shelf and Franklin Bay are attributed to high inputs of fresh organic matter. Meiofaunal composition changed in relation to their affinity to phytodetritus: nematodes seemed to be more adapted to degraded phytodetritus, while turbellarians and kinorhynchs were correlated with fresh phytodetritus in the summer (Bessière et al. 2007).

Although the meiofaunal composition seemed to be influenced by seasonal variations of organic matter inputs to the benthos, the southeast Beaufort Sea macrofaunal community composition showed spatial variations (Conlan et al. 2008) between the Mackenzie shelf and the gulf area, even though the difference was not explained by the presence of the polynya. Benthic macro- and megafauna respond more to environmental forcing than micro- and meiofauna (Gage \& Tyler 1991), so their distribution and structure are expected to integrate variations at longer time scales (Piepenburg 2005). Interestingly, SCD also showed spatial variations and was lower in the gulf than on the shelf ( $t$-test, $\mathrm{p}<0.05)$. As seen previously, the gulf area shows more degraded pigments and a stable isotopic composition typical of marine origin. Benthic activities (SCD) and community compositions might reflect these differences in organic matter inputs.

\section{CONCLUSIONS}

The combination of sedimentary pigments and stable isotope measurements allowed us to identify spatial and seasonal variations of organic matter inputs to the benthos of the eastern Beaufort Sea. Sedimentary pigments reflected seasonal variations in the pelagicbenthic coupling. In the summer, inputs of 'fresh' organic matter to the benthos were related to the overlying production. The main degradation process is through zooplankton grazing. In the fall, there is evidence of rapid deposition of small algal cells to the sea floor, with material also being generally more degraded. Inputs from the river were also an important source of arriving material in the fall. Sedimentary pigments also suggested that in the gulf area, most material reaching the sea floor was heavily degraded, probably due to microbial degradation. Stable isotopes highlighted spatial differences between the shelf and the gulf area. The shelf area is under the influence of terrestrial inputs, while in the gulf, material reaching the sea floor is from a more marine origin.
Acknowledgements. Thanks are due to CCGS 'Amundsen' officers and crew, as well as the CASES scientists. We are extremely grateful to J. Perl (San Diego State University Research Foundation) for providing pigment standards. Thanks to C. Lehmann for running the sedimentary isotope samples and to M. Benjamin for assisting with the preparation of samples at the Environment Canada stable isotope facility. This manuscript benefited from comments made by $\mathrm{S}$. Shumway, M. Gosselin, B. Fitzgerald, and 3 anonymous reviewers. This investigation is part of the project CASES financed by NSF (OPP-0326371 to P.E.R.) and the University of Connecticut.

\section{LITERATURE CITED}

Altabet MA (1988) Variations in nitrogen isotopic composition between sinking and suspended particles: implications for nitrogen cycling and particle transformation in the open ocean. Deep-Sea Res 35:535-554

> Ambrose WG Jr, Renaud PE (1995) Benthic response to water column productivity patterns-evidence for benthicpelagic coupling in the Northeast Water Polynya. J Geophys Res C 100:4411-4421

Ambrose WG Jr, Renaud PE (1997) Does a pulsed food supply to the benthos affect polychaete recruitment patterns in the Northeast Water Polynya? J Mar Syst 10:483-495

Ambrose WG, von Quillfeldt C, Clough LM, Tilney PVR, Tucker T (2005) The sub-ice algal community in the Chukchi sea: large- and small-scale patterns of abundance based on images from a remotely operated vehicle. Polar Biol 28:784-795

> Anderson T, Sarmiento JL (1994) Redfield ratios on remineralization determined by nutrient data analysis. Global Biogeochem Cycles 8:65-80

> Bessière A, Nozais C, Brugel S, Demers S, Desrosiers G (2007) Metazoan meiofauna dynamics and pelagic-benthic coupling in the Southeastern Beaufort Sea, Arctic Ocean. Polar Biol 30:1123-1135

> Bianchi TS, Dawson R, Sawangwong P (1988) The effects of macrobenthic deposit-feeding on the degradation of chloropigments in sandy sediments. J Exp Mar Biol Ecol 122:243-255

Boon AR, Duineveld GCA (1996) Phytopigments and fatty acids as molecular markers for the quality of near-bottom particulate organic matter in the North Sea. J Sea Res 35: 279-291

Buchaca T, Catalan J (2007) Factors influencing the variability of pigments in the surface sediments of mountain lakes. Freshw Biol 52:1365-1379

Carmack EC, Macdonald RW (2002) Oceanography of the Canadian Shelf of the Beaufort Sea: a setting for marine life. Arctic 55:29-45

Carmack EC, Macdonald RW, Jasper S (2004) Phytoplankton productivity on the Canadian Shelf of the Beaufort Sea. Mar Ecol Prog Ser 277:37-50

Carroll ML, Carroll J (2003) The Arctic Seas. In: Black KD, Shimmield GB (eds) Biogeochemistry of marine systems. Blackwell Publishing, Oxford, p 126-156

Chen NH, Bianchi TS, McKee BA, Bland JM (2001) Historical trends of hypoxia on the Louisiana shelf: application of pigments as biomarkers. Org Geochem 32:543-561

Clough LM, Ambrose WG Jr, Cochran JK, Barnes C, Renaud PE, Aller RC (1997) Infaunal density, biomass and bioturbation in the sediments of the Arctic Ocean. Deep-Sea Res II 44:1683-1704

> Clough LM, Renaud PE, Ambrose WG (2005) Impact of water depth, sediment pigment concentration, and ben- 
thic macrofauna biomass on sediment oxygen demand in the Western Arctic Ocean. Can J Fish Aquat Sci 62: 1756-1765

Conlan K, Aitken A, Hendrycks E, McClelland C, Melling H (in press) Distribution patterns of Canadian Beaufort Shelf macrobenthos. J Mar Syst

> Cooper LW, Larsen IL, Grebmeier JM, Moran SB (2005) Detection of rapid deposition of sea ice-rafted material to the Arctic Ocean benthos using the cosmogenic tracer 7Be. Deep-Sea Res II 52:3452-3461

Cremer H (1999) Spatial distribution of diatom surface sediment assemblages on the Laptev Sea shelf (Russian Arctic). In: Kassens H, Bauch HA, Dmitrenko I, Eicken H and others (eds) Land-ocean systems in the Siberian Arctic: dynamics and history. Springer-Verlag, Berlin, p 533-551

> Daly KL, Wallace DWR, Smith WO, Skoog A and others (1999) Non-Redfield carbon and nitrogen cycling in the Arctic: effects of ecosystem structure and dynamics. J Geophys Res C 104:3185-3199

Dittmar T, Kattner G (2003) The biogeochemistry of the river and shelf ecosystem of the Arctic Ocean: a review. Mar Chem 83:103-120

> Dunton KH, Weingartner T, Carmack EC (2006) The nearshore western Beaufort Sea ecosystem: circulation and importance of terrestrial carbon in arctic coastal food webs. Prog Oceanogr 71:362-378

Fahl K, Stein R, Gaye-Haake B, Gebhardt C, Kodina LA, Unger D, Ittekkot V (2003) Biomarkers in surface sediments from the $\mathrm{Ob}$ and Yenisei estuaries and the southern Kara Sea: evidence for particulate organic carbon sources, pathways, and degradation. In: Stein R, Fahl K, Futterer DK, Galimov AM, Stepanets OV (eds) Siberian river runoff in the Kara Sea: characterisation, quantification, variability and environmental significance, Vol 6. Elsevier, Amsterdam, p 329-348

Forest A, Sampei M, Hattori H, Makabe R and others (2007) Particulate organic carbon fluxes on the slope of the Mackenzie Shelf (Beaufort Sea): physical and biological forcing of shelf-basin exchanges. J Mar Syst 68:39-54

Forest A, Sampei M, Makabe R, Sasaki H and others (2008) The annual cycle of particulate organic carbon export in Franklin Bay (Canadian Arctic): environmental control and food web implications. J Geophys Res C 113:C03S99

Gage JD, Tyler PA (1991) Deep-sea biology: a natural history of organisms at the deep-sea floor. Cambridge University Press, Cambridge

Gieskes WWC, Kraay GW (1984) Phytoplankton, its pigments, and primary production at a central North Sea station in May, July and September 1981. Neth J Sea Res 18:51-70

Goñi MA, Yunker MB, Macdonald RW, Eglinton TI (2000) Distribution and sources of organic biomarkers in arctic sediments from the Mackenzie River and Beaufort Shelf. Mar Chem 71:23-51

Gosselin M, Levasseur M, Wheeler PA, Horner RA, Booth BC (1997) New measurements of phytoplankton and ice algal production in the Arctic Ocean. Deep-Sea Res II 44: 1623-1644

Graf G, Gerlach SA, Linke P, Queisser W and others (1995) Benthic-pelagic coupling in the Greenland-Norwegian Sea and its effect on the geological record. Geol Rundsch 84:49-58

Grant J, Hargrave B, MacPherson P (2002) Sediment properties and benthic-pelagic coupling in the North Water. Deep-Sea Res II 49:5259-5275

Grebmeier JM, Barry JP (1991) The influence of oceanographic processes on pelagic-benthic coupling in polar regions: a benthic perspective. J Mar Res 2:495-518
Hobson KA, Ambrose WG Jr, Renaud PE (1995) Sources of primary production, benthic-pelagic coupling, and trophic relationships within the Northeast Water Polynya: insights from $\delta^{13} \mathrm{C}$ and $\delta^{15} \mathrm{~N}$ analysis. Mar Ecol Prog Ser 128:1-10

Hoffman JC, Bronk DA (2006) Interannual variation in stable carbon and nitrogen isotope biogeochemistry of the Mattaponi River, Virginia. Limnol Oceanogr 51:2319-2332

Holm-Hansen O, Lorenzen CJ, Holms RW, Strickland JD (1965) Fluorometric determination of chlorophyll. J Cons Int Explor Mer 30:3-15

Jeffrey SW, Vesk M (1997) Introduction to marine phytoplankton and their pigment signature. In: Jeffrey SW, Mantoura RFC (eds) Phytoplankton pigments in oceanography. UNESCO, Paris, p 37-84

Klages M, Boetius A, Christensen JP, Deubel H, Piepenburg D, Schewe I, Soltwedel T (2004) The benthos of the Arctic seas and its role for the organic carbon cycle at the seafloor. In: Stein R, Macdonald RW (eds) The organic carbon cycle in the Arctic Ocean. Springer, Berlin, p 139-167

Kowalewska G (2005) Algal pigments in sediments as a measure of eutrophication in the Baltic environment. Quat Int 130:141-151

Kowalewska G, Szymczak-Zyla M (2001) Influence of selected abiotic factors on the decomposition of chlorophylls. Oceanologia 43:315-328

Kowalewska G, Witkowski A, Toma B (1996) Chlorophylls C in bottom sediments as markers of diatom biomass in the southern Baltic Sea. Oceanologia 38:413-432

Leavitt PR, Carpenter SR (1990) Aphotic pigment degradation in the hypolimnion: implication for sedimentation studies and paleolimnology. Limnol Oceanogr 35:520-534

Leavitt PR, Hodgson DA (2001) Sedimentary pigments. In: Smol JP, Birks HJN, Last WM (eds) Tracking environmental change using lake sediments, Vol 3. Terrestrial, algal, and siliceous indicators. Kluwer Academic Publishers, Dordrecht, p 295-325

Louda JW, Li J, Li J, Winfree MN, Baker EW (1998) Chlorophyll-a degradation during cellular senescence and death. Org Geochem 29:1233-1251

Lovejoy C, Legendre L, Price NM (2002) Prolonged diatom blooms and microbial food web dynamics: experimental results from an Arctic polynya. Aquat Microb Ecol 29: $267-278$

Lovejoy C, Massana R, Pedros-Alio C (2006) Diversity and distribution of marine microbial eukaryotes in the Arctic Ocean and adjacent seas. Appl Environ Microbiol 72: 3085-3095

Lovejoy C, Vincent WF, Bonilla S, Roy S and others (2007) Distribution, phylogeny, and growth of cold-adapted picoprasinophytes in Arctic seas. J Phycol 43:78-89

Lovvorn JR, Cooper LW, Brooks ML, De Ruyck CC, Bump JK, Grebmeier JM (2005) Organic matter pathways to zooplankton and benthos under pack ice in late winter and open water in late summer in the north-central Bering Sea. Mar Ecol Prog Ser 291:135-150

Macdonald RW, Solomon SM, Cranston RE, Welch HE, Yunker MB, Gobeil C (1998) A sediment and organic carbon budget for the Canadian Beaufort Shelf. Mar Geol 144:255-273

Mackey MD, Mackey DJ, Higgins HW, Wright SW (1996) CHEMTAX - a program for estimating class abundances from chemical markers: application to HPLC measurements of phytoplankton. Mar Ecol Prog Ser 144:265-283

Mantoura RFC, Llewellyn CA (1983) The rapid determination of algal chlorophyll and carotenoid pigments and their breakdown products in natural waters by reverse-phase high-performance liquid chromatography. Anal Chim Acta 151:297-314 
Matthiessen J, Kunz-Pirrung M, Mudie PJ (2000) Freshwater chlorophycean algae in recent marine sediments of the Beaufort, Laptev, and Kara Seas (Arctic Ocean) as indicators of river runoff. Int J Earth Sci 89:470-489

McCallister SL, Bauer J, Cherrier JE, Ducklow HW (2004) Assessing sources and ages of organic matter supporting river and estuarine bacterial production: a multiple-isotope $\left(\Delta^{14} \mathrm{C}, \delta^{13} \mathrm{C}\right.$, and $\left.\delta^{15} \mathrm{~N}\right)$ approach. Limnol Oceanogr 49: $1687-1702$

McMahon KW, Ambrose WG Jr, Johnson BJ, Sun MY, Lopez GR, Clough LM, Carroll ML (2006) Benthic community response to ice algae and phytoplankton in Ny Ålesund, Svalbard. Mar Ecol Prog Ser 310:1-14

> McQuoid MR, Godhe A, Nordberg K (2002) Viability of phytoplankton resting stages in the sediments of a coastal Swedish fjord. Eur J Phycol 37:191-201

Miyake Y, Wada E (1971) The isotope effect on the nitrogen in biochemical, oxidation-reduction reactions. Rec Oceanogr Work Jpn 11:1-6

Morata N, Renaud PE (2008) Sedimentary pigments in the western Barents Sea: a reflection of the pelagic-benthic coupling? Deep-Sea Res II (in press)

> Naidu AS, Scalan RS, Feder HM, Goering JJ and others (1993) Stable organic carbon isotope in sediments of the north Bering-south Chukchi seas, Alaskan-Soviet Arctic Shelf. Cont Shelf Res 13:669-691

Not F, Massana R, Latasa M, Marie D and others (2005) Late summer community composition and abundance of photosynthetic picoeukaryotes in Norwegian and Barents Sea. Limnol Oceanogr 50:1677-1686

O'Brien MC, Macdonald RW, Melling H, Iseki K (2006) Particle fluxes and geochemistry on the Canadian Beaufort Shelf: implications for sediment transport and deposition. Cont Shelf Res 26:41-81

Olli K, Wexels Riser C, Wassmann P, Ratkova T, Arashkevich E, Pasternak A (2002) Seasonal variation in vertical flux of biogenic matter in the marginal ice zone and the central Barents Sea. J Mar Syst 38:189-204

Parsons TR, Maita Y, Lalli CM (1984) A manual of chemical and biological methods for seawater analysis. Pergamon Press, Toronto

Parsons TR, Webb DG, Dovey H, Haigh R, Lawrence M, Hopky GE (1988) Production studies in the Mackenzie River-Beaufort Sea estuary. Polar Biol 8:235-239

Parsons TR, Webb DG, Rokeby BE, Lawrence M, Hopky GE, Chiperzak DB (1989) Autotrophic and heterotrophic production in the Mackenzie river/Beaufort Sea estuary. Polar Biol 9:261-266

Peterson BJ, Holmes RM, McClelland JW, Vörösmarty CJ and others (2002) Increasing river discharge to the Arctic Ocean. Science 298:2171-2173

Piepenburg D (2005) Recent research on Arctic benthos: common notions need to be revised. Polar Biol 28:733-755

Pirtle-Levy R, Grebmeier JM, Cooper LW, Larsen IL, DiTullio GR (in press) Seasonal variation of chlorophyll a in Arctic sediments implies long persistence of plant pigments. Deep-Sea Res II

Polyakova YI (2003) Diatom assemblages in surface sediments of the Kara Sea (Siberian Arctic) and their relationship to oceanological conditions. In: Stein R, Fahl K, Futterer DK, Galimov AM, Stepanets OV (eds) Siberian river run-off in the Kara Sea: characterisation, quantification, variability and environmental significance, Vol 6. Elsevier, Amsterdam, p 375-399

Rachol V, Hubberten HW (1999) Carbon isotope composition of particulate organic material in East Siberian rivers. In: Kassens H, Bauch HA, Dmitrenko I, Eicken H and others (eds) Land-ocean systems in the Siberian Arctic: dynamics and history. Springer-Verlag, Berlin, p 223-239

Redfield AC, Ketchum BH, Richardson FA (1963) The influence of organisms on the composition of sea-water. In: Hill MN (ed) The sea. Ideas and observations on progress in the study of the seas, Vol 2. The compositions of sea-water. Comparative and descriptive oceanography. Interscience, New York, p 26-77

Renaud PE, Riedel A, Michel C, Morata N, Gosselin M, JuulPedersen T, Chiuchiolo A (2007a) Seasonal variation in benthic community oxygen demand: a response to an ice algal bloom in the Beaufort Sea, Canadian Arctic? J Mar Syst 67:1-12

Renaud PE, Carroll ML, Ambrose WG Jr (2007b) Effects of global warming on Arctic sea-floor communities and its consequences for higher trophic levels. In: Duarte C, Agustí S (eds) Impacts of warming on polar ecosystems. FBBVA Press, Madrid, p 139-175

Renaud PE, Morata N, Ambrose WG Jr, Bowie JJ, Chiuchiolo A (2007c) Carbon cycling by seafloor communities on the eastern Beaufort Sea shelf. J Exp Mar Biol Ecol 349:248-260

> Renaud PE, Morata N, Carroll ML, Denisenko SG, Reigstad M (2008) Pelagic-benthic coupling in the western Barents Sea: processes and time scales. Deep-Sea Res II (in press)

> Richardson TL, Jackson GA (2007) Small phytoplankton and carbon export from the surface ocean. Science 315:838-840

Sakshaug E (2004) Primary and secondary production in the Arctic Seas. In: Stein R, Macdonald RW (eds) The Arctic carbon cycle in the Arctic Ocean. Springer, Berlin, p 57-81

- Sancetta C (1981) Diatoms as hydrographic tracers: example from Bering Sea sediment. Science 211:279-281

Scheer H (1991) Structure and occurrence of chlorophylls. In: Scheer H (ed) The chlorophylls. CRC Press, Boca Raton, FL, p 3-30

Sherr EB, Sherr BF, Wheeler PA, Thompson K (2003) Temporal and spatial variation in stocks of autotrophic and heterotrophic microbes in the upper water column of the central Arctic Ocean. Deep-Sea Res I 50:557-571

Smith CR, Mincks S, DeMaster DJ (2006) A synthesis of bentho-pelagic coupling on the Antarctic shelf: food banks, ecosystem inertia and global climate change. Deep-Sea Res II 53:875-894

Soltwedel T, Schewe I (1997) Activity and biomass of the small benthic biota under permanent ice-coverage in the central Arctic Ocean. Polar Biol 19:52-62

Stein R, Macdonald RW (2004) Organic carbon budget: Arctic Ocean vs. global ocean. In: Stein R, Macdonald RW (eds) The organic carbon cycle in the Arctic Ocean. Springer, Berlin, p 315-322

Suzuki K, Minami C, Liu HB, Saino T (2002) Temporal and spatial patterns of chemotaxonomic algal pigments in the subarctic Pacific and the Bering Sea during the early summer of 1999. Deep-Sea Res II 49:5685-5704

Takahashi T, Broecker WS, Langer S (1985) Redfield ratio based on chemical data from isopycnal surfaces. J Geophys Res 90:6907-6924

> Tamelander T, Renaud PE, Hop H, Carroll ML, Ambrose WG Jr, Hobson KA (2006) Trophic relationships and pelagic-benthic coupling during summer in the Barents Sea Marginal Ice Zone revealed by stable carbon and nitrogen measurement. Mar Ecol Prog Ser 310:33-46

Tremblay JE, Gratton Y, Fauchot J, Price NM (2002) Climatic and oceanic forcing of new, net, and diatom production in the North Water. Deep-Sea Res II 49:4927-4946

Verity PG, Vernet M (1992) Microzooplanton grazing, pigments, and composition of plankton communities during late spring in two Norwegian fjords. Sarsia 77:263-274 
Vidussi F, Roy S, Lovejoy C, Gammelgaard M and others (2004) Spatial and temporal variability of the phytoplankton community structure in the North Water Polynya, investigated using pigment biomarkers. Can J Fish Aquat Sci 61:2038-2052

Villanueva J, Hastings DW (2000) A century-scale record of the preservation of chlorophyll and its transformation products in anoxic sediments. Geochim Cosmochim Acta 64:2281-2294

von Quillfeldt CH (1997) Distribution of diatoms in the Northeast Water Polynya, Greenland. J Mar Syst 10:211-240

von Quillfeldt CH (2000) Common diatom species in arctic spring blooms: their distribution and abundance. Bot Mar 43:499-516

Walsh JJ, Dieterle DA, Maslowski W, Grebmeier JM and others (2005) A numerical model of seasonal primary production within the Chukchi/Beaufort Seas. Deep-Sea Res II 52:3541-3576

Wassmann P, Reigstad M, Haug T, Rudels B and others (2006)

Editorial responsibility: Peter Verity,

Savannah, Georgia, USA
Food webs and carbon flux in the Barents Sea. Prog Oceanogr 71:232-287

Wells LE, Cordray M, Bowerman S, Miller LA, Vincent WF, Deming JW (2006) Archaea in particle-rich waters of the Beaufort Shelf and Franklin Bay, Canadian Arctic: clues to an allochthonous origin? Limnol Oceanogr 51:47-59

Wexels Riser C, Wassmann P, Reigstad M, Seuthe L (2008) Vertical flux regulation by zooplankton in the northern Barents Sea during Arctic spring. Deep-Sea Res II (in press)

Wright SW, Jeffrey SW, Mantoura RFC, Llewellyn CA, Bjornland T, Repeta D, Welschmeyer N (1991) Improved HPLC method for the analysis of chlorophylls and carotenoids from marine phytoplankton. Mar Ecol Prog Ser 77:183-196

> Wu P, Wood R, Stott P (2005) Human influence on increasing Arctic river discharges. Geophys Res Lett 32:L02703

> Yunker MB, Macdonald RW, Veltkamp DJ, Cretney WJ (1995) Terrestrial and marine biomarkers in a seasonally ice-covered Arctic estuary-integration of multivariate and biomarker approaches. Mar Chem 49:1-50

Submitted: January 24, 2008; Accepted: August 2, 2008 Proofs received from author(s): October 27, 2008 